\title{
Perichoretic interaction within the Trinity as a paradigm for fostering unity in the Public Affairs Committee (PAC) in Malawi
}

\author{
Qeko Jere \\ North-West University, Potchefstroom, South Africa \\ pjereqekoh@gmail.com
}

\begin{abstract}
The revival of the patristic doctrine of perichōrēsis in relation to the Trinitarian framework has received overwhelming support in modern theological discourse. From Anagorous to John of Damascus, and from reformation to the $21^{\text {st }}$ century theological scholarship, the doctrine of perichōrēsis has been viewed by many as a palatable approach and a suitable paradigm in addressing various challenges affecting the church and society globally, because it is out of this patristic doctrine that the entire doctrine of the Trinity is sustained. If it was not for perichōrēsis neither nature, personal, or salvific doctrine of Trinity would have no value. If not for perichōrēsis, Arianism, encompassing all aspects of modalism with various assorted gods within Christianity, would be a global phenomenon. This article presents perichōrēsis as the paradigm in advancing a national unity agenda within the Church and State in conjunction with a case study of the Public Affairs Committee in Malawi, which is a representation of the voice of the faith community in addressing the national unity agenda and other governance issues. The main argument in the paper is that adoption and emulation of the immanent Trinitarian perichoretic life experienced within the Trinitarian community of the Father, Son and the Holy Spirit is the best way forward in bringing meaningful unity in society today. This is because perichōrēsis, which flows within the Trinitarian framework, is the model and an example of what humans and society must emulate to enhance unity and togetherness.
\end{abstract}

Key words

Perichōrēsis; Trinity; national unity; public affairs committee; regionalism; church

\section{Introduction and background}

National unity has been a critical issue in all political dispensations in Malawi's political economy. The roadmap to fostering national unity in 
Malawi demands a critical examination of how the question of unity and nationhood was tackled within the nation's historical framework. From the beginning of the nation's history, colonialism, which followed the footsteps of the Church (Jere 2013:70-71), divided the nation into three administrative, ethnic and regional blocks; north for Tumbuka, centre for Chewas and south for Yaos, Lomwes and Senas (Kaspin 1995:598). By 1891, all areas under the spheres of missionaries were declared a British protectorate and this included the three major aforementioned administrative blocks (Nyasaland Colonial Report no 1156:4). According to Kaspin (1995:602) and Chirwa (1998:55-57) when Dr Banda and the MCP assumed power in 1964 , they inherited a polity in which the major administrative boundaries were already drawn. It was, however, during the three decades of $\mathrm{Dr}$ Banda's MCP reign that intensified and hugely promoted regionalism and ethnic divisions in the country. Through the four corner stones of Unity, Obedience, Royalty and Discipline (Cammack \& Kanyongolo 2010:11), Dr Banda declared that there were no Yao, Sena, Chewa, Ngoni, Nyakyusa, Tonga or Lomwe in Malawi (Mkandawire 2010:23) although he, himself openly identified himself as a Chewa from the Kasungu district in the central region (Kamwendo 2002:144). Dr Banda believed that the Chewa people and Chewa culture were the core of modern Malawi by right of being most ancient and least compromised by colonialism, and Malawi culture would be considered synonymous with Chewa culture (Vail \& White 1989:182). Short (1974:93) and Kaspin (1997:490-491) add that Dr Banda equated 'Malawian-ness' with 'Chewa-ness', and he depicted the Chewa as the very soul of the country and despite denouncing tribalism, he frequently emphasized that he was a Chewa.

\subsection{Dr Banda's segregation and discrimination of the northern and southern region}

The intensified pressure for Dr Banda's separatist, oppressive and sidelining of people from the northern and southern regions was apparent after the 1964 Cabinet Crisis (Kamwendo 2002:144, Phillips 1976) where a team of educated Cabinet Ministers from the regions questioned the style of leadership and policy that was being followed (Kaspin 1995:603). In retaliation, Dr Banda and the MCP created a patronage system to segregate, discriminate and oppress northerners and southerners in the following ways: deposed some chiefs and dissolved three and six district 
councils in the northern and southern region while the central region remained intact in support of Dr Banda's action (Vail \& White 1989:179); made the central region the focus for development and investment without considering the northern or the southern region (Vail \& White 1989: 181); declared Chichewa, in 1968, as the only official local language for media, and printing in Malawi (Kaspin 1995:607, Mkandawire 2010:29); shifted the nation's capital from Zomba in the southern region to Lilongwe in the central region (his home base) (Kaspin 1995:477, 609) to consolidate more power from within his central region; introduced the Department of Chichewa and Linguistics at the University of Malawi (Kaspin 1997:483) and assigned the Chichewa Board to monitor and steer the development of Chichewa (Kamwendo 2002:141); declared that to qualify for places in secondary schools, northerners and southerners were supposed to obtain considerably high marks (Short 1974:274); raised school fees to make northerners and southerners fail to access education since they were economically disadvantaged; ordered ethnic cleansing of the non-Chewa administrators at the University of Malawi; and finally, forced retirement at fifty for Senior Civil Servants from the north and southern region respectively was implemented (Vail \& White 1989:183).

The heart of Dr Banda segregation and systematic discrimination was revealed in 1987 through the quota system and the 1989 forced repatriation of all teachers from the north into their motherland (Mkandawire 2010:34). According to Kaunda (1998:428) this was a systematic form of official discrimination, oppression and patronage where Banda monopolised most of the State's benefits. Scholars (Kaunda 1998:429-430, Kalipeni 1997:151153, Patel \& Wahman 2015, Short 1974) agree that Dr Banda's policy during his thirty years of autocratic rule segregated and systematically oppressed and discriminated against the people of the northern and southern regions - an action which helped to unify the oppressed populations in the fight for multiparty democracy.

\subsection{Electoral voting, and deepening ethnicity and regionalism in post-Banda Malawi}

The notion that Dr Banda boasted about his version of a united Malawi nation was proven wrong with the birth of freedom. Scholars (Kaspin 1995, Kalipeni 1997, Ferree \& Horowitz 2010, Thorold 2000) agree that 
the multiparty elections in Malawi revealed the deep regional and ethnic divisions that were systematically promoted during Dr Banda's threedecade rule. Kaunda (1998:429) highlights that post-Banda Malawi, revealed deep fragmentation and division in the country where three major ethnic, linguistic and regional blocks of the north, centre and south are apparent. However, Ferree and Horowitz (2010:534-536) assert that apart from the 2009 elections, the voting pattern during the 1994, 1999, and 2004 elections followed a predictable regional voting with citizens lining up behind 'regional champions.

Kalipeni (1997:165) calls voting pattern the 'three super-ethnic identities' that shaped the voting pattern in Malawi's multiparty democracy, starting with the Referendum in 1993 where the north and the south pulled 84 and 83 percent of regional vote while the central region gave Dr Banda 66 percent (Kalipeni 1997:156-158). Kaspin (1995:596) however comments that the 1994 election was driven by group loyalty, with each of the three administrative regions supporting its home candidate where the southern region had Muluzi and the UDF (78 percent), the central region had Banda and MCP (64 percent), and the northern region had Chakufwa Chihana (88 percent) (Dulani \& Van Donge 2005:203-208). Similarly, in the 1999 election, there was the interplay of ethnic and regional factors where Muluzi got 78 present in the south, Chakuamba managed to get 61 percent of the vote in the central region and had 88 percent in the north (Thorold 2000:137-138). Regionalism and the ethnic pattern of voting was obvious just as it was in the 2004 general election where Ferree and Horowitz (2010:537) say that the MCP's John Tembo won the central region, his home base, with 64\% percent, while Muthalika, on a UDF ticket, got 53 percent from the Lomwe and Yao, while the northern region block supported the Chakuamba's Mgwilizano Alliance with 73 percent under Mgode (Ferree \& Horowitz 2010:538).

However, a look into the 2014 election, Patel and Wahman (2015:80) contend that even the tripartite elections showed a return to regionalist patterns of voting, where according to Zeze (2015:185) the central region gave Chakwera 58 percent, the southern region gave Muthalika 56 percent, the northern region gave Joyce Banda 56 percent, while Atupele took majority of the vote in the Yao-built eastern region. Kalipeni (1997:155) squarely says that Dr Banda's policy of segregation and discrimination against 
the people of the northern and southern region was fully responsible for the creation of the super ethnic identity in Malawi. Having looked into unity challenges in Malawi, the author submits that it is not just hearsay that there is deep social political and economic division and disunity in Malawi because even political parties are regional with very deep ethnic connections (Khaila \& Chibwana 2005:3).

However, attempts have been made by the church to address the problem of disunity in Malawi particularly after the 1994 democratic change and birth of democracy. This is because during the pre-democratic Malawi (196494), the church remained silent and did little to speak against division and segregation (Ross 1995:57), because it was too close to the Banda regime (Kansilanga 1995). However, in the 1992-94 Church reawakening prophetic mission led in the fight against one party state and every manner of divisions (Ross 1996:114) and the formation of the Public Affairs Committee (also called PAC in this paper) to represent and have all churches speak with one voice on matters of national interest (Ross 1996:113, Van Dijk 1998:172).

\subsection{Theoretical justification}

Perichōrēsis is the theoretical framework that has governed and informed this study in addressing unity in Malawi. Theologically perichōrēsis depicts the fellowship that takes place within the Trinitarian community where the Persons dwell and stay in the other and for the other and are one (Williams 2004:633). This explains of the three Persons that eternally co-exist from eternity are not only distinct but are also totally equal through perichōrēsis (Williams 2004:17) where every action of God even if through one of the Persons has the total involvement of the other two (Williams 2009:92). While I engage Perichoretic theoretical framework, I also recognise the fact that there are scholars (Kilby 2000, Tanner 1992, Tuggy 2004, Hasker 2010) who view perichōrēsis as taking side with social Trinitarians. At this juncture I am not dealing with technical aspects of Social Trinity but only using perichōrēsis in taking care of the Malawi unity discourse. A wider touch on technical implication of social Trinity in relation to perichōrēsis would be properly deal with in my next paper. However how can God who is one also exist in three Trinitarian Persons? How do unity, equality and distinction exist within the three Trinitarian Persons? The unity of God is seen through the lenses of the unity of the Three Trinitarian Persons 
of the Father, Son and the Holy Spirit where though they are distinct, the Persons are equal and united through perichōrēsis. For Prestige (1959:298) perichōrēsis is understood as the ground of unity between divine persons. Perichōrēsis tells of the three major Trinitarian operative frameworks, unity, equality and distinctiveness, which are key pillars that this study is based on (Miller 2007:4-5).

The justification in the application of this paradigm is seen through the lenses of the Church embodying the Trinitarian unity and translating it to a workable unity action in society. Thus Perichōrēsis is the perfect paradigm in promoting relations and unity within the Church and society (Otto 2001:366-380, Marmion 2009:108). Even though some scholars (Volf 1998, Kilby 2000, Tanner 1992, Tuggy 2004) question the use of perichōrēsis, in this context this theoretical concept is the right one that would properly make sense in addressing the unity question in Malawi, since the Church has been the dominant force in the nation political economy since its inception. The paper argues that unless the Church mirrors and embodies perichoretic Trinitarian unity in its operation, oppression and various forms of segregations will never stop within society. By extension, if the Church effectively emulates the Trinitarian unity then the state and society would, in turn, copy the ecclesial unity. Disunity in the Church signifies failure of embodying and understanding the unity of God in the Trinity. LaCugna (1993:393) and Frame (2002:694-695) rightly argue that perichōrēsis effectively addresses all concerns on the question of the divine monarchy being responsible in justifying earthly dominion and thereby promotes unity. This paper, therefore, examines perichoretic interaction within the Trinity as a paradigm in addressing the challenge of national unity in Malawi through the Public Affairs Committee, which represents all churches in the consolidation of democracy. Thus just as, perichoretically, the Persons are distinct, equal and remain united in the Godhead, the Church would remain united with distinct operations within the Public Affairs Committee's operational framework in Malawi. This is recognising the fact that $80 \%$ of the nation's population belong to Christian Church, which has historically played a crucial role in influencing the political destiny of the nation (Phiri 2014:73-75, International Religious Freedom Report 2012:1-3). The paper proposes the best practice that needs to be adopted if the church in the PAC has to continue adding value in unifying the country. 


\section{Perichoretic conceptual framework for national unity}

Perichōrēsis can be defined as the Trinitarian system that governs and sustains the Trinitarian community and remains the engine that adds value to the entire Christian faith. Scholars (Lampe 1968:1077-1078, Baker 1983:107-109, Moltman 2000:113, Scalise 2012:58) agree that the Greek noun Perichōrēsis derives from Greek word, "peri" meaning, "round" and chorein, meaning, "to make room for or to go forward and contain" while the verb perichōreō means to "go around, interchange interpenetrate, to dance around and encircling one another". Moltman (2000:114) asserts that in Latin, perichōrēsis, circumincessio and circuminsessio mean the dynamic interpenetration (incedere) and mutual indwelling (insedere) as agreed in the Council of Florence declaration of 1438-45 (Marmion \& Van Nieuwenhove 2012:206-207). For LaCugna (1993:271) perichōrēsis means "being in one another, permeation without confusion", while for Williams (2009:92), the three Persons are mutually involved with each other to such a degree that they are one. According to Stamatović (2016:303-304) and Boff (1988:135) perichōrēsis expresses the mutual indwelling and containment among the Persons of the Trinity. Volf (1998:209) however presents perichōrēsis as the reciprocal interiority of the Trinitarian persons stating that in every divine person as a subject, the other persons also indwell; all mutually permeate one another, though in so doing they do not cease to be distinct persons. Horsthuis (2011:91) comments that the word perichōrēsis captures the idea that the Father, Son and the Spirit mutually dwell in one another.

Originally, perichōrēsis was applied in Christology to understand the humanity and divinity of Christ (Lawler 1995:49-50), In the development of perichōessis, the Eastern Church fathers borrowed from Anaxagorus the use of a verb (perichōreō) to mean revolution, making room for another around oneself, which they later contextualized in Christological and Trinitarian Theology (Sahinidou 2014:552, Disandro 1984:442-447).

Williams (2009:91) says that perichōrēsis was brought in to make simple the fundamental difficulty in understanding the Trinity, though Crisp (2005:120) notes that it is impossible to have a precise analysis of perichōrēsis because it is a divine mystery. It was the Cappadocian fathers who simplified the usage of perichōrēsis in relation to Christology and the Trinitarian operation (Gunton 1995:92-110, Crisp 2005:121). Tipton (2002:294) says that the perichoretic push came into being to address 
Modalism, Arianism and Tritheism. In the language of critical scholars (Crisp 2005:122, Otto 2001:368, Artemi 2017:21-25) Gregory of Nazianzus in the $4^{\text {th }}$ Century was the first father to employ the term perichōrēsis in a theological sense in relation to the humanity and divinity of Christ. Behr (2004:42) and Prestige (1959:290-291) add that Gregory provides Christological significance to the verb "perichoreo" referring to the two natures of Christ. However, it was in the $7^{\text {th }}$ Century that Maximus Confessor drew from Gregory's Christological use of "perichore $\bar{o}$ " (Fiddes 2000:73-74, Scalise 2012:67-68) and was the first Christian writer to give to the term perichōrēsis a central position within orthodox Christology (Thunberg 1995:26-27). However, it was John of Damascus who in the $8^{\text {th }}$ Century popularized the word for both Christology and doctrine of the Trinity (Moltman 2000:113, Stamatović 2016:307). Nevertheless, there are fundamental principles that govern the existence and operation of the Trinitarian Persons perichoretically as follows.

\subsection{Perichoretic unity}

Unity is one of the major characteristics and principles within the Trinitarian perichoretic governance and every sector of life. Kelly (1960:268) contends that Gregory of Nyssa draws attention to the Trinitarian operation of the Father, Son and Spirit while Gregory of Nazianzus emphasizes the unity of the divine Persons being real, as opposed to the national unity of several men. Now where does perichoretic unity reside and how do we understand it? Perichoretic unity is that which enables the effective unification process in the indwelling and interpenetration of the Persons into the other. LaCugna 1993:270-271) locates perichoretic unity in the communion of the persons of the Father, Son and the Holy Spirit. She further states that perichōrēsis avoids locating the divine unity either in the divine essence or in the person of the Father.

I thus share the notion that if it was not for perichoretic unity, the entire Trinitarian operation would fail to realize its mission within the redemptive plan. Williams (2013:3) rightly say that perichoretic unity enables effective inter-relationships. Athanasius recognized the unity of God and the three Trinitarian Persons numerically as one substance (Rusch 1986:26) which, according to Crampton (1995:2), is within the Person of the Trinity where Father, Son and the Holy Spirit are equal and one. For Peters (1993:36) 
the Son can be identified as the Son only by virtue of his relationship to the Father and the Spirit where His interaction with the other two and not independent. Trinitarian unity enhances Trinitarian relations within the community of Persons of Father, Son and the Holy Spirit (Kiesling 1986:606).

\subsection{Perichoretic distinctiveness}

The Trinity involves distinction (Williams 2000:116). In what way are the Trinitarian Persons distinct from each other? Though there is unity of the Trinitarian Persons (having the same substance-ousia), there exist distinction in the Person in terms of their operation in fulfilling creation and salvific plan where the Father created, the Son incarnate and the Spirit sustained (Williams 2009:89). In their distinct operation in fulfilling redemption plan, the Father cannot be the Son or the Spirit because it has to be the Son who has to incarnate. According to Williams (2009:89) the only difference between the Persons is in their distinct relationships so that the Father is different from the Son as Begetter, is distinct from Begotten through Perichōrēsis. Thus while in their Trinitarian unity they perichoretically dwell and interpenetrate the other, at the same time, they maintain their uniqueness and differences. Therefore, the ability to fulfil all perichoretic missions lies in their distinctiveness since it is in their distinctiveness that the Father has to be the Father, the Son the Son and the Spirit the Spirit. For Grudem (1994:231) God is three distinct Persons the Father, the Son and the Holy Spirit, while for Cunningham (1969:268) and Erickson (1985:321) the three Trinitarian Persons are distinct while possessing one and the same divine nature and essence and have a peculiar character that enhances the collaboration process. Erickson (1985:338) says that each Person of the Trinity has, for a period of time, performed a particular, distinct function unique to himself, which does not affect their essence or substance but instead makes collaboration possible within the Trinitarian community.

\subsection{Perichoretic equality}

Equality is a vital component in the life and operation of God within the Trinitarian community of the Father, Son and the Holy Spirit. Now how are the Trinitarian Person equal and where does the equality of the Persons resides? LaCugna (1993:272) says that the mutuality and equality of the 
Persons resides in the divine substance which is equal and the same. It is due to their equality that they are able to interpenetrate and dwell in the other (Williams 2013:3) meaning that if they were not equal, then the entire Trinity would be rendered dead. For Gregory of Nazianzus (Oration 20,6), every action of God is the action of the Three. Thus Artemi (2013:139) comments that no one person of the Trinity acts independently of or in isolation from the others and the action of each is the action of all; the action of all is the action of each and essentially one. Trinitarian perichoretic equality is all about equal sharing of substance in the Person of the Trinity to such an extent that they are one. Thus, equality is the very characteristic of the divine Persons. Erickson (1985:339) notes that there is equality in the Persons of the Trinity through perichōrēsis, which is the action that causes the Persons to be equal. The significance of equality is seen in that it enhanced total unity and every aspect of relations in addition to collaborations within the distinctiveness in Trinitarian operations.

\section{Public Affairs Committee (PAC) and the national unity enquiry}

At the helm of the national unity enquiry in Malawi's political economy, is the faith based organization called the Public Affairs Committee (PAC), which was the engine for political transition from the one-party to a multiparty system of government (Hussein 2011:30, Newell 1994:31). This was championed by the CCAP Presbyterian General Synods (Blantyre and Livingsonia Synods), the Episcopal Conference of Malawi (Roman Catholic Church) and Anglican Church (Mitchell 2002:15) with Nkhoma Synod missing in action (Newell 1995:257, Schofelleer 1999:260-261). Others, like Malawi Council of Churches, Muslims and representatives of pressure groups joined later (Brown 2004:707). The PAC was born five months after the release of the pastoral letter by the Catholic Church on 8 March, 1992 entitled, "Living Our Faith" (Ross 1997:386), which was the genesis for the fight for total freedom in Malawi (Newell 1994:9-10). The formation of this entity signified the importance and influence the Church had had in the nation's political economy since inception.

Established on the $28^{\text {th }}$ of August, 1992, the Public Affairs Committee was originally called the National Affairs Committee of Malawi (NACM) (Schoffeleers 1999:232). On 28 September, 1992, in a meeting that took 
place at St Pauls Cathedral in Blantyre, delegates decided to change the name from National Affairs Committee of Malawi (NACM) to Public Affairs Committee (PAC) removing, "Malawi" so as to avoid having to ask permission for the use of "Malawi" in the title (Schofelleers 1999:247). According to Kansilanga (Schoffeleers 1999:249) the PAC was put together and spearheaded by the Church, which was an integral part of the community, and invited and involved all able and willing participants in its dialogue with the MCP Government for a political change in Malawi. The various Malawian churches accept the PAC as their representative institution influencing politics in Malawi (Patel, Tambulasi, Malonde, Mpesi 2007:49). The PAC Constitution's (2007:6-7) main goal and objective was to put pressure on the State in addressing national issues and to also help create the culture of the church's prophetic voice, while at the same time, leading in dialogue on issues of national interest, promoting peace, tranquillity, and respect for the rule of law and human rights (Schofelleers 1999:248, Hussein 2011:30). According to Van Doepp (1998:109), the PAC is geared to provide the Church with a common voice in all matters of national interest.

\subsection{PAC major highlights during 1994-2017}

The first major and outstanding highlight during the reign of Bakili Muluzi was the PAC's battle to stop Muluzi from amending section 83(3) to allow for his third or open term in office in 2002 (Nowack 2018: 16-19), inspiring strong opposition from the PAC and the entire Church. Posner and Young (2007:133) as well as Dulani and Van Donge (2005:217-220) state that the PAC categorically argued that the proposed amendment was unconstitutional. During the reign of Bingu wa Muthalika, a PAC highlight involved mediation talks between the Muthalika government and opposition members of parliament who demanded the speaker to evoke section 65 for all MPs who crossed the floor to join the newly formed Democratic Progressive Party (Chinsinga 2008:12, Chilenga 2008:52-54). However, in the second term of President Bingu wa Muthalika, until his death in 2012, the PAC was crucially involved in mediating talks between government and the various stakeholders who accused government of human rights abuses, which climaxed with the death of 18 people on 20 July, 2011 and the call for a referendum (Mbaya 2014:256-257, Shawa 2012:50-51). 
During the brief reign of Joyce Banda, the PAC's main focus was the implementation of Section 64 and 65 of the Constitution to declare vacant seats of those MPs who defected to other parties (PAC 2013:1-2, PAC 2014:13) just like what it did during Bingu wa Muthalika's reign (Joala 2012:61). The PAC wanted the Speaker of Parliament to declare vacant all seats of MPs who left their parties and joined Joyce Banda's Peoples Party (Tsoka 2013:2, Gunde 2015:7). The current reign (2017) of Arthur Peter Muthalika has been critical and called government to address corruption, regionalism, tribalism and nepotism (PAC 2014:1-5). Critical for corruption has been the PAC's call for government to probe the MK577 billion, in addition to other Cash Gate corruption cases (PAC 2016a:2). In their communiqué of September, 2015, the PAC underscored that corruption, Section 65 and the sale of MBS Bank needed to be amicably addressed (PAC 2015:1-7) in addition to making the call to turn the current DPP into a National Prosecution Authority (PAC 2016:1-4).

\subsection{PAC successes and challenges}

Upon its establishment in 1992, the PAC represented Malawians in dialoguing with the Presidential Committee on Dialogue (PCD) which was the team Dr Banda established to negotiate with the opposition on all political matters (Chirambo 1998:202, Chirambo 2004:158, Kanyongolo 1998:364). The PAC also became the umbrella body for all Malawians in the fight against the one-party system of Dr Banda (Newell 1995:258). In addition, the PAC initiated the formation of the National Consultative Council (NCC) and the National Executive Council (NEC) to take care of the political transition to multiparty democracy in Malawi (Hofmeyr 2004:1322, Van Donge 1995:233). For Kasambara (1998:245) and Scholefeleers (1999:284), the PAC played a crucial role in referendum electoral civic education and all the other elections, while for Banda (1998:321), the PAC was the leading organisation in aid of systematising the all-party constitutional conference that led to the birth of the nation's new constitution (Tamani 2007:1-3) in addition to hosting mediation talks (PAC 2013:1-5).

However, the first major challenge for the PAC has been the government accusation that the organisation is working with the opposition and has a sinister agenda to overthrow government (Bisani 2017). For instance, in 
2011-2012 the Bingu wa Muthalika government accused the PAC of being bedfellow with the opposition and wanting to bring chaos in the country (Mbaya 2014:256) while during the $20176^{\text {th }}$ all-inclusive conference, government again accused the PAC of divorcing itself from its principles and that it has been captured by the opposition parties and acted militantly (Dausi 2017). The second challenge has been regionalism, tribalism and religion, where some PAC members are alleged to have aligned themselves with their political masters instead of the organization. For instance, some Pentecostal churches and Muslim councils supported Muluzi's third term bill (Wochi 2002) and some influential clergy did not support the PAC's 2017, $6^{\text {th }}$ all-inclusive conference approach (Maulana 2017, Mkandawire 2017). Thirdly, of the PAC's lack of capacity to effectively carryout conflict preventative, monitoring, evaluation and peace building at all levels was criticised (Hussein 2011:38). Although the PAC has structures, the institution does not have adequate skilled and competent specialist members to effectively deal with complex issue of peace, negotiation, peace building and conflict resolution (Hussein 2011:37).

\section{Towards integrating perichoretic principles for national unity}

\subsection{PAC perichoretic unity for ecclesial mutual relations and cooperation}

A kingdom and a house divided against itself cannot stand (Lincoln 1858:1, Mk 3:24-26), and without unity there is no true and meaningful nationhood (Nyerere 1997). This statement expresses the significance of unity, nationhood and the church. Jesus prayed for the disciples and the Church to be united and remain one with common mission and purpose (Jn 17:21-23). The seriousness of unity is that it is derived from the Trinitarian unity life of the Persons. LaCugna (1993:1-2) contends that the life of God does not belong to God alone but that it is about God's life with us and our life with each other that is relational. Consequently, how does Trinitarian perichoretic unity life get translated into an action for unity in the PAC, Church and society? A clear response is that the Church within the PAC, which carries the light of Christ, must embody the unity of God within the Trinitarian community and translate that into unity within the PAC. The 
Church must be a model of true unification whether it entails Augustinian or Cappadocian unity is inconsequential; so long as unity prevails within the ecclesia for mutual relations and cooperation. For the PAC, this would mean that the Catholics, Presbyterians, Lutherans, Pentecostals, Methodist and Anglicans would enhance ecclesial unity where the Church would take common position in all matters of national interest with no contradiction as has been the case lately. This would be the demonstration of internal perichoretic ecclesial unity, which promotes the oneness of Christ within the Church. Perichoretic Trinitarian ecclesial unity enables the Church leaders to rise above the political demands of ethnicity, regionalism and any form of segregations. Failure of the Church leaders to embody the Trinitarian operations, and in this case unity, has led to Church leaders compromising their position and submitting to the political demands in support of the political activities in their region and ethnic groups, as was the case with CCAP Nkhoma synod and Muslim council in 1992-94 and 2002 respectively (Hofmeyr 2004:1322).

\subsection{PAC perichoretic distinctiveness for effective collaboration and partnership}

The uniqueness of Trinitarian Person is a crucial paradigm in the realisation of Trinitarian set goals. Distinctively, the Father is the Father and not the Son and that the Son is neither the Father nor the Holy Spirit, who basically work in total collaboration within the Trinitarian community (Kiesling 1986:608). This statement begs the question, how would the unique characteristics of the Trinitarian Person be perichoretically translated into an action for the PAC and the Church to establish an effective collaboration and partnership? Regarding this, the Church must embody Trinitarian distinctiveness where each PAC member must have a special responsibility to fulfil in realizing the PAC mandate for the nation. Just like perichōrēsis remains the reason behind every Trinitarian success, the same would be the factor to enhance unique perichoretic collaboration with the PAC members as they utilise their capacity to the advantage of the organisation. Just like the Trinity recognizes internal difference, the PAC must, likewise, recognize and appreciate the uniqueness of each member in terms of what each can contribute to the PAC's working framework. Also, just like the Persons perichoretically embrace each other's differences, the Church in the PAC must internally compromise and accept to collaborate with others 
so as to utilise the capacity of each for the betterment of the PAC so that it may actualise its desired goals. The author, therefore, agrees with Boff (2000:54) who contends that distinctiveness must exist but must not be define without the other; meaning, within Church differences, there also must be interrelation and dependability and collaboration within the PAC.

\subsection{PAC perichoretic equality for effective participation and mutual existence}

Equality, as a concept, is critical in enhancing unity at every level of development. Even constitutions of nations demand that all people exist equally under the law as expressed in the Constitution of both Malawi and South Africa (Constitution of Malawi, sec 12(5), South African Constitution Sec 9(6)). Theologically, equality enhances free participation of the Trinitarian Persons perichoretically within the Godhead through an interpenetrated and mutual existence in the other (Boff 2000: xiii). But, how does perichoretic equality become an entity in addressing division and misunderstandings within PAC? Also, how does equality enhance capacity building within the PAC? And, how does equality promote effective participation and mutual existence within PAC? Regarding these questions, perichoretic equality gives a good paradigm and example of how the Church within the PAC could equally participate in the life of the other. Thus, this equality in the Trinity has to be the embodiment of the equality in the Church before the same extends to society. Just like perichoretic equality enhances the person to exist mutually, within the PAC, the Church would mutually exist in relation to the others as they equally, at all levels, support and agree to the agendas within the organisation's advocacy framework, for the betterment of the country. Equality would mean that members would have to rise above all differences and focus on that which is equally beneficial to all. Allegedly, the PAC's internal misunderstandings have arisen due to Church leaders failing to rise above their differences and maintain their equality of purpose. Since equality does not promote divisions and absolute control within the PAC, all members are equal in terms of authority and influence nationally. It is the lack of equality within the PAC that some PAC executives went as far as questioning and undermining the organisation's position on some critical issues of national interest. 


\section{Realising a perichoretic unified nation}

In an effort to realise a united nation, there are three major action plans that need to be implemented in Malawi as discussed in sections 5.1, 5.2 and 5.3 respectively.

\subsection{PAC and the Church must rise above state politics}

The church, which is critical in the consolidation of democracy in Malawi, must rise above the demands of state politics if it is to achieve its Godgiven mandate. How can the PAC rise above such political demands, which sometimes are very lucrative and attractive? Within the PAC governance system, some Church leaders have been accused of being critical of the PAC because they are too close to the arm of the state (Munthali 2017) and are looking for favours. It is due to poverty, ethnicism and regionalism that within the PAC some members are either for or against government. Furthermore, the welfare of the church and the saints should be prioritised over privileges just like in the Trinitarian community. In other words, the welfare of the lost humanity should be made a priority through both incarnation and creation.

\subsection{The Church must be a model of unity in the PAC and the nation}

Perichoretic unity is crucial and it enables the Persons of the Trinity to interpenetrate and dwell in the other, the emulation of which unites the Church in every sphere of its operation. The Church must embody the Trinitarian perichoretic unity where true unity is practiced. Based on the unity practiced within the Trinity, the Church must emulate and apply such in carrying out its operation within the PAC. This unity must be translated into an action for the Church where each would mutually exist in relation to the other and cooperate in all activities within the PAC. The antagonism and divisions that are seen where some sectors within the PAC would do contrary to agreed resolutions, tells of the problem that the Church leadership normally experience. Lack of the Church's embodiment of the divine life of God has led to the disintegration of society in many different ways. The danger is that by staying closer to the state power, the Church runs the risk of endorsing specific policy proposals from the State (Van Rekend \& Vander Meulen 1999:200) at the expense of the people. Therefore, the Church in the PAC must embrace, compromise and rise 
above every form of division and maintain ecclesiological unity. The author thus submits that unless the Church emulates and practices perichoretic unity, which is modelled on the Trinitarian community itself, divisions will forever exist to the detriment of ecclesial growth.

\subsection{PAC and the Church must not compromise prophetic role}

An uncompromised prophetic role is the other fundamental action that the Church body and the entire PAC need to maintain so as to protect the distinct space that the organisation fills within the nation's social political economy. The author realises that different schools of thought on the PAC's position on some issues; others claim that the PAC is doing little to help address the suffering of ordinary people and that there has to be a moment when it has to boldly and persistently speak out against evil perpetuated by the regime (Munthali 2017) while some feel that the PAC is confrontational and aggressively presenting itself as a political party (Bvumbwe 2017, Maulana 2017, Dausi 2017). However, to say that the PAC must not compromise its prophetic mission means that it must act as a check and balance on behalf of the poor citizenry, rebuking government and even the opposition parties; each time both fail to do their assigned constitutional tasks. The failure of government symbolises the failure of opposition parties also to carry out their respective mandate in strongly rebuking government and at the same time providing alternative solutions and an action plan for the country to move forward. Thus, the author submits that the scenario where the PAC criticises government and ignores the failures of the opposition, it defeats its own prophetic role in a public square that needs to be holistic and not one sided.

\section{Conclusion}

This paper has explored the perichoretic interaction within the Trinity as a paradigm in fostering unity in the PAC in Malawi. In the application of perichoretic principles, the paper engaged three aspects of the principle perichoretic: unity, distinctiveness and equality, which served as a springboard concerning what needs to be done if within the PAC, Church unity has to be properly translated into unity action for the nation. 


\section{References}

Artemi, E 2017. The Term Perichōrēsis from Cappadocian Fathers to Maximus Confessor. International Journal of European Studies, $1(1): 21-29$.

Artemi, E 2013. Gregory Nazianzen's Trinitarian teaching based on his Twentieth Theological Oration. De Medio Aevo, 4(2)126-146.

Baker, SK 1983. Fundamentals of Catholicism: God, Trinity, Creation, Christ, Mary. New York, Ignatius Press.

Banda, J 1998. The Constitutional Change Debate of 1993-1995. In K Phiri and K Ross (eds). Democratization in Malawi:A Stocktaking. Blantyre: Christian Literature Association of Malawi (CLAIM). 316333.

Behr, J 2004. Formation of Christian Theology. The Nicene Faith, Part 2. Crestwood: St Vladimir's Seminary Press.

Bisani, 1 2017. PAC wants to oust Mutharika. Malawi24 news. [Online]. Available: https://malawi24.com/2017/04/22/pac-wants-oust-mutharika.

Boff, L 1988. Trinity and Society. Maryknoll: Orbis.

Boff, L 2000. Holy Trinity, perfect community. Maryknoll, NY: Orbis

Brown, S 2004. Born-Again Politicians Hijacked our Revolution":

Reassessing Malawi's Transition to Democracy. Canadian Journal of African Studies 38(3):705-722.

Bvumbwe, J 2017. PAC at crossroad-Interview by Lucky Mkandawire. The Nation. 10/5/17.

Cambridge: Cambridge University Press.

Cammack, D \& Kanyongolo, E 2010. Local governance and public goods in Malawi. Africa Power and Politics Working Paper No. 11. Overseas Development Institute, London.

Chilenga, M 2008. Dikastocracy: is it undermining democracy in Malawi. In Towards the Consolidation of Malawi's democracy, essays in honour of the work of Albert Gisy, German ambassador in Malawi (February 2005-June 2008. Konrad-Adenauer-Stiftung Occasional paper no 11. Malawi. 
Chinsinga, B 2008. Malawi's democracy project at a crossroads. In Towards the consolidation of Malawi's democracy, essays in honour of the work of Albert Gisy, German Ambassador in Malawi (February 2005-June 2008). Konrad-Adenauer-Stiftung Occasional paper no 11. Malawi.

Chirambo, R 1998. Malawian Literature under Dr Kamuzu Banda and its Place in the New Democratic Malawi. Tizame (6):28-32.

Chirambo, R 2004. Operation Bwezani: the army, political change, and Dr. Banda's

Hegemony in Malawi. Nordic Journal of African studies, 13(2):146-163.

Chirwa, WC 1998. The Constitutional Change Debate of 1993-1995. In K Phiri and K Ross (eds). Democratization in Malawi: A Stocktaking. Blantyre:Christian Literature Association of Malawi (CLAIM). 52-69.

Crampton, W.G 1995. The Biblical doctrine of the Trinity. Trinity Review, $1-5$.

Constitution of the republic of Malawi the people of Malawi, Lilongwe.

Constitution of the republic of South Africa, 6 December 1996, Pretoria.

Crisp, OD 2005. Problems with Perichōrēsis. Tyndale Bulletin, 56(1):119140.

Cunningham, W 1969. Historical Theology: a review of the principal doctrine discussions. In The Christian church since the Apostolic Age. London: Banner of Truth Trust.

Dausi, N 2017. Vote of no confidence in the Public Affairs Committee. Press Statement: Ministry of Information and Communication Technology.

Disandro, CA 1984. Historia semantica de perikhoresis. Studia patricitica 15(1):442-447.

Dulani, B \& van Donge, JK 2005. A Decade of Legislature-Executive Squabble in Malawi (1994-2004). In Salih Muhamed. (ed). African Parliaments: Between Governments and Governance. London: Palgrave Macmillan. 201-224.

Erickson, MJ 1985. Christian Theology. Grand Rapids: Baker Books. 
Ferree, K \& Horowitz, J 2010. Ties that bind? The rise and decline of ethno-regional partisanship in Malawi, 1994-2009. Democratization 17(3):534-563.

Fiddes, PS 2000. Participating in God: a pastoral doctrine of the Trinity. London: Darton, Longman \& Todd.

Frame, J 2002. The doctrine of God, a Theology of Lordship. Edited by John Frame. Phillipsburg: P\&R Publishing.

Gunton, CE 1995. "Relation and relativity: The Trinity and the created world." In Christoph Schwobel (ed). Trinitarian Theology Today: essays on divine Being and act. Edinburgh: T \& T Clark.

Gregory of Nazianzus, Oration 20, 6. On Theology, and the Appointment of Bishops, SC 270, 6, (PG 35, 1072B).

Grudem, W 1994. Bible doctrine. Downers Grove: Inter-Varsity Press.

Gunde, AM. The political role of the media in the democratisation of Malawi: The case of the Weekend Nation from 2002 to 2012. Thesis for a doctor's degree in philosophy (Journalism). Stellenbosch: Stellenbosch University.

Hasker, W 2010. Objections to Social Trinitarianism. Religious Studies. 44:(421-439), doi:10.1017/S0034412510000107.

Hofmeyr, JW 2004. Post-independent mainline churches in Africa (19752000). HTS Teologiese Studies/ Theological Studies. 60(4):1307-1332.

Horsthuis, J 2011. Participating with God: A perichoretic Theology of Leadership. Journal of Religious Leadership. 10(1):81-106.

Hussein, MK 2011. Intra-state conflict and indigenous-based conflict resolution mechanisms in Malawi: the role of the Public Affairs Committee. African Security Review. 20(1):26-39.

Jere, PMQ 2013. Church and State: A comparative theological study of the ministry of the Church in national development in Malawi, Zambia and Zimbabwe. Thesis for a doctor's degree in theology. University of Fort Hare, South Africa.

Joala, R 2012. The super-inflation of the presidency in Malawi. African Security Review. 21(4):57-63. 
Kalipeni, E 1997. Regional polarization in voting pattern: Malawi's 1994 Election. African Journal of Political Science. 2(1):152-67.

Kamwendo, GH 2002. Ethnic Revival and Language Associations in the New Malawi: The Case of Chitumbuka. In A Democracy of Chameleon, edited by Harri Englund. Blantyre: CLAIM. 140-150.

Kansilanga, M 1995. Church and politics in Malawi today. Workshop, Chongoni.

Kanyongolo FE 1998. The limit of liberal constitutionalism in Malawi. In K Phiri and K Ross (eds). Democratization in Malawi: A Stocktaking. Blantyre: Christian Literature Association of Malawi (CLAIM). 353374.

Kasambara, R 1998. Civic Education in Malawi since 1992: An Appraisal. In Kings M Phiri and Kenneth R Ross (eds). Democratization in Malawi: A Stocktaking. Blantyre, Malawi: CLAIM.

Kaspin D 1997. Tribes, Regions and Nationalism in Democratic Malawi. In Ian Shapiro and Will Kymlicka (eds). Ethnicity and Group Rights. New York: NYU Press. 464-503.

Kaspin, D 1995. The Politics of Ethnicity in Malawi's Democratic Transition. In The Journal of Modern African Studies 33(4):595-620.

Kaunda, JM 1998. The State and Society in Malawi. Journal of Commonwealth and Comparative Politics, 36(1):48-67.

Kelly, JND 1960. Early Christian Doctrine. London: Adam \&Charles Black.

Khaila, K \& Chibwana, C 2005. Ten years of democracy in Malawi: Are Malawians getting what they voted for? Afrobarometer working papers. No. 46.

Kiesling, OP 1986. On relating to the Persons of the Trinity. Theological issues. (14):599-616.

Kilby, K (2000). Perichōrēsis and Projection: Problems with Social Doctrines of the Trinity. New Blackfriars. 81:432-445. http://dx.doi. org/10.1111/j.1741-2005.2000.tb06456.x 
LaCugna, CM 1993. God for us: The Trinity and the Christian life. San Francisco: Harper Collins.

Lampe,GWH 1968. A Patristic Greek Lexicon. Oxford: Clarendon Press.

Lawler, MG 1995. Perichōrēsis: New Theological Wine in an Old Theological Wineskin. Horizons. 22(1):52-53.

Lincoln, A 1858. House Divided. Speech (16 June 1858). Springfield, Illinois.

Marmion, D 2009. Trinity and Salvation: A Dialogue with Catherine LaCugna. Irish Theological Quartery. (74):115-129.

Marmion, D \& Van Nieuwenhove, R 2012. An introduction to the Trinity. Cambridge:Cambridge University Press.

Maulana, A 2017. Interview: PAC Divisions in Malawi. North-West University, 12/817.

Mbaya, H 2014. Human Rights - the tension and conflict between Church and State in Malawi 2004-2012. Nederuitse Gereformeede Teologiese Tydskrif. 55(1):249-264.

Miller, DL 2007. The Importance of the Trinity in Building Healthy Cultures, Equipping Churches, Transforming Communities, Disciplining Nations. Phoenix, Arizona: Disciple Nations Alliance.

Mitchell, M 2002. Living Our Faith: The Lenten Pastoral Letter of the Bishops of Malawi and the Shift to Multiparty Democracy, 1992-1993. Journal for the Scientific Study of Religion. 41(1):5-18.

Mkandawire, L 2017. Bvumbwe mum on mother body PAC support. The Nation, 22 June.

Mkandawire, B 2010. Ethnicity, language, and cultural violence: Dr. Hastings Kamuzu Banda's Malawi, 1964-1994. The Society of Malawi Journal. 63(1):23-42.

Moltman, J 2000. Perichōrēsis: An Old Magic Word for a New Trinitarian Theology. In Trinity, Community and Power: Mapping Trajectories in Wesleyan Theology. M Dauglas Meeks (ed). Nashville, TN:

Kingswood. 112-125. 
Munthali, M 2017. Phone Interview: PAC division in a democratic dispensation. North-West University, 11/9/17.

Newell, J 1994. Democracy popular precedents, practice and culture.

Paper presented at a History Workshop. University of Witwatersrand, 13-15 July 1994, South Africa.

Newell, J 1995. A Moment of Truth? The Church and Political Change in Malawi, 1992. The Journal of Modern African Studies. 33(2):243-262.

Nowack, D 2018. Cultural Values, Attitudes, and Democracy Promotion in Malawi: How Values Mediate the Effectiveness of Donor Support for the Reform of Presidential Term Limits and Family Law. Discussion Paper. Deutsches Institut für Entwicklungspolitik, Tulpenfeld, Bonn.

Nyasaland Colonial Report, NO.1156, Annual General Report for the year 1921. Geographical and historical. Imperial House, Kingsway, London.

Nyerere, MJ 1997, Without unity, Africa has no future. Speech delivered in Accra on the 6th of March 1997, Ghana's 40th anniversary of independence. Accra: Ghana.

Otto, RE 2001. The Use and Abuse of Perichōrēsis in Recent Theology. Scottish Journal of Theology. 54(3), 373.

PAC, 2013. Report on the Post-Conference Strategy Meeting Held at Mount Soche Hotel, $30^{\text {th }}$ April. Public Affair Committee, Lilongwe.

PAC, 2014. Restoring Democratic and Economic Governance: A consolidated and Analytical Overview of Response and commitment of political parties. Public Affairs Committee Head Quarters: Lilongwe.

PAC, 2015. Report of the Public Affairs Committee on the Question of Federalism and Inclusivity in Malawi. Communiqué: Lilongwe.

PAC, 2016. $5^{\text {th }}$ All-inclusive stakeholders conference held on 17-18 February 2016 at Mount Soche Hotel, Blantyre. Communique, PAC: Lilongwe. 
PAC, 2016a. PAC, chairperson's presentation on recommendations, issues and actionable resolutions during interface meeting with head of state and government of Malawi on 21 April, 2016 at Lilongwe State House.

Patel, N \& Wahman, M 2015. The Presidential, Parliamentary and Local Elections in Malawi, May 2014. Africa Spectrum (1):79-92.

Patel, N, Tambulasi, R, Molande, B, Mpesi, A 2007. Consolidating democratic governance in Southern Africa: Malawi. EISA Research Report, No. 33. Johannesburg, South Africa.

Peters, T 1993. God as Trinity: rationality and temporality in divine life. Louisville: John Knox Press.

Phillips, EH 1976. HBM Chipembere: Malawi Patriot. UFAHAMU. VII(1):5-17.

Phiri, MJM 2014. Secular humanism in Malawi: a historical-theological inquiry. Dissertation presented for the degree of Master of Theology, Stellenbosch University, South Africa.

Posner, DN \& Young, DJ 2007. The institutionalization of political power in Africa. Journal of Democracy 18(3):126-140.

Prestige, GL (1956) 1959. God in patristic thought. London: SPCK.

Ross, K 1997. Crisis and identity - Presbyterian Ecclesiology in Southern Malawi, 1891-1993. Missionalia 25(3):375-391.

Ross, KR 1996, Where were the Prophets and Martyrs in Banda's Malawi? Four Presbyterian Ministers. Missionalia 24(2):113-128.

Ross, KR 1995. The Kingdom of God and Contemporary Politics: Theological Reflection on Social Transformation in Malawi. Missionalia 23(1):57-71.

Rusch, W 1986. The Trinitarian controversy. Philadelphia: Fortress.

Sahinidou, I 2014. Christological Perichōrēsis. Open Journal of Philosophy. (4):552-559.

Scalise, BT 2012. Perichōrēsis in Gregory Nazianzen and Maximus the Confessor. Eleutheria. 2(1):58-76. 
Schoffeleers, M 1999. In search for the truth: Confrontation between Church and State in Malawi 1960-1994. Kachere Book 8. Blantyre: CLAIM.

Shawa, LB 2012. The big-man syndrome as a security threat in Malawi: A critical theory perspective. Southern African Peace and Security Studies. 1(2),:44-56.

Short, P 1974. Banda. London: Routledge \& Kegan Paul.

Stamatović, S 2016. The Meaning of Perichōrēsis. Open Theology. (2):303323.

Tanner, K 1992. The Politics of God. Minneapolis: Augsburg Fortress.

Tamani, B 2007. Mediation attempts and challenges: A case of Public Affairs Committee (PAC). Public lecture presented at Chancellor College, Centre for Peace and Conflict Management. University of Malawi: Zomba.

Tipton, LG 2002. The function of perichōrēsis and the divine incomprehensibility. WTJ. 64:289-306.

Thorold, A 2000. Regionalism, tribalism and multiparty democracy: The case of Malawi. Southern African Journal of International Affairs. 7(2):135-139. https://doi.org/10.1080/10220460009545321

Thunberg, L 1995. Microcosm and Mediator: The Theological Anthropology of Maximus the Confessor (2nd ed). Open Court Publishing Co, Peru, IL.

Tsoka, MG. A Tale of Two Presidents: Assessments of Chitsulo Cha Njanje and Amayi in Malawi. Afrobarometer Briefing Paper. No. 121.

Tuggy, D 2004, Divine deception, identity, and Social Trinitarianism. Religious Studies. 40(1):269-287.

Vail, L and White, L 1989. Tribalism in the Political History of Malawi. In Vail, Leroy (editor). The Creation of Tribalism in Southern Africa. London Berkeley: Currey University of California Press. 151-184. 
Van Doepp, P 1998. The kingdom beyond Zasintha: Churches and political life in Malawi's post-authoritarian era. In K Phiri and K Ross (eds). Democratisation in Malawi: A Stocktaking. Blantyre: CLAIM. 102-26.

Van Reken, CP \& Vander Meulen, P 1999. The Church's Role in Social Justice. Calvin Theological Journal. (34):198-202.

Van Dijk, RA 1998. Pentecostalism, Gerontocratic Rule and Democratisation in Malawi: The Changing Position of the Young in Political Culture. In J Haynes (ed.). Religion, Globalisation and Political Culture in the Third World. MacMillan:London.

Van Donge, JK 1995. Kamuzu's Legacy: The Democratization of Malawi: Or Searching for the Rules of the Game in African Politics. African Affairs. 94(375):227-257.

Volf, M 1998. After Our Likeness: The Church as the Image of the Trinity. Grand Rapids: Eerdmans.

Williams, DT 2000. New Century Trinity. Alice: University of Fort Hare.

Williams, DT 2004. Kenōsis and the nature of the Persons in the Trinity. Koers. 69(4):623-640.

Williams, DT 2004. Vinculum Amoris, A Theology of the Holy Spirit. New York: Universe, IInc.

Williams, DT 2009. kenōsis of God: The self-limitation of God-Father, Son, and Holy Spirit. Bloomington: iUniverse.

Williams, DT 2013. Perichōrēsis and the South African ideal. Koers Bulletin for Christian Scholarship. 78(1), Art. \#2118, 7 pages. http:// dx.doi.org/10.4102/ koers.v78i1.2118.

Wochi, O 2002. Malawi Muslims support Muluzi third term bid. PanaPress News. [Online]. Available: http://www.panapress.com/MalawiMuslims-support-Muluzi-third-term-bid--13-460373-17-lang2-index.html [Accessed: on $6 / 9 / 17]$.

Zeze, WSD 2015. Democratic Constitution and Ethnic Organizations in Malawi: Preserving Good Culture or Promoting, Regionalism, Nepotism and Tribalism. History Research 5(3):169-187. 